The Fate of the Partner's Mortgage after Division A Comparative analytical study in the Iraqi Civil Code

\author{
Hallo Mohammed Salih Abdulsamad \\ College of Law and Political Science, \\ Kirkuk University, Republic of Iraq \\ ha.dzdai@uokirkuk.edu.iq \\ Safaa Shakoor Abaas \\ College of Law and Political Science, \\ Kirkuk University, Republic of Iraq \\ safaa@uokirkuk.edu.iq \\ Fryad Shukur Hussein \\ College of Law and Political Science, \\ Kirkuk University, Republic of Iraq \\ fryaddalo76@gmail.com
}




\title{
The Fate of the Partner's Mortgage after Division A Comparative analytical study in the Iraqi Civil Code
}

\section{Hallo Mohammed Salih Abdulsamad Safaa Shakoor Abaas Fryad Shukur Hussein}

\begin{abstract}
In-kind insurance has an important role to play in guaranteeing the creditor's right. It is therefore important in the economic and social life, money circulation and trade continuity where it is treated as a special guarantee for the creditor, which gives him privileges so that he favors general insurance in priority and follows the in kind insurance.

Hence, the importance of in specie insurance that creditors prefer to other personal insurance is being noticed. The comparative analytic approach is adopted by analyzing some of the Iraqi civil law texts and comparing them with the Jordanian and Egyptian Civil Codes to find out some gaps in the Iraqi Civil Code.
\end{abstract}

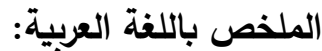

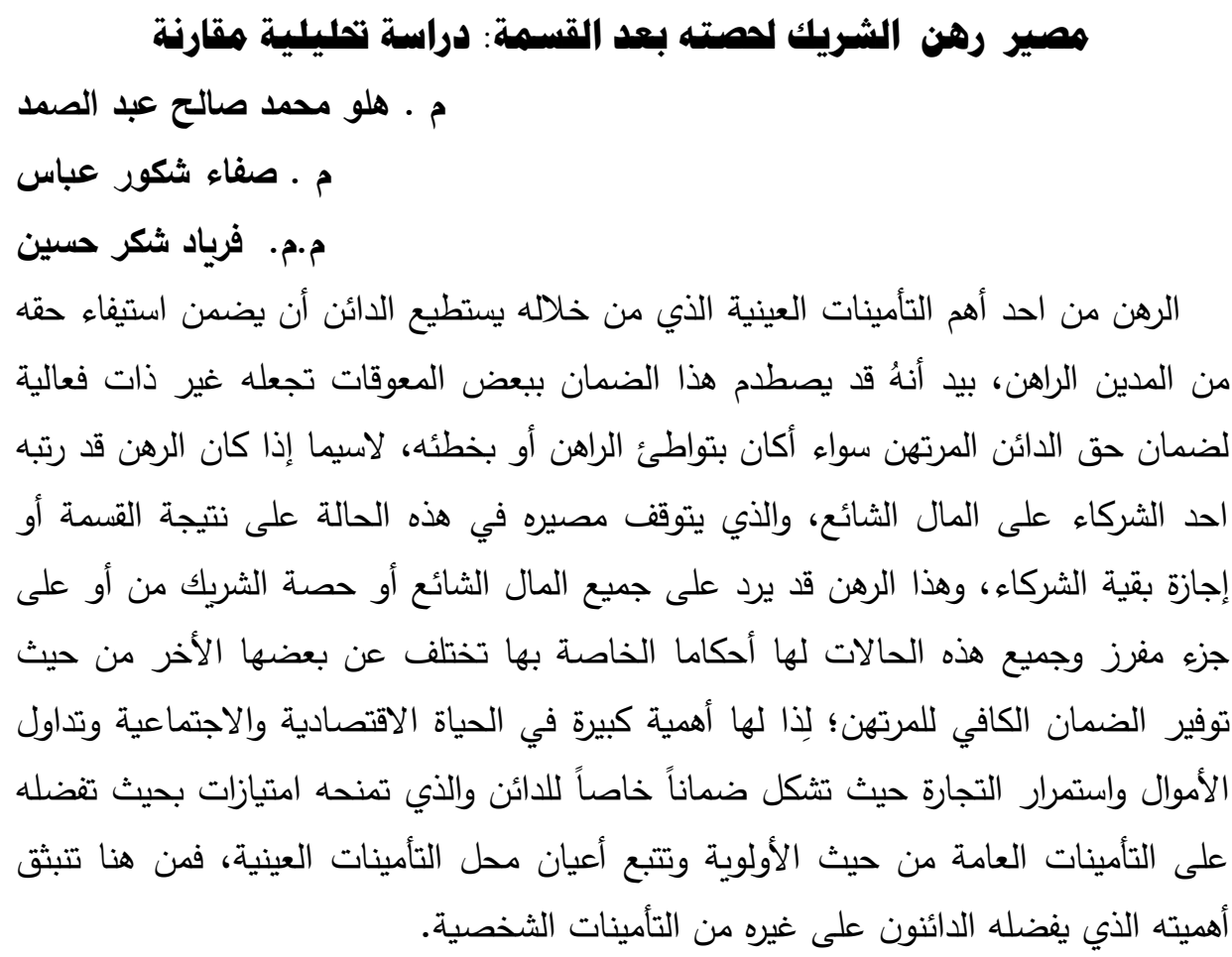


The Fate of the Partner's Mortgage after Division

A Comparative analytical study in the Iraqi Civil Code

Hallo Mohammed Salih Abdulsamad

Safaa Shakoor Abaas

Fryad Shukur Hussein

مجلة وادي النيل للاراسات والبحوث الإنسانية والاجتماعية والتربوية (مجلة علمية محكمة)

\section{Introduction}

A mortgage is one of the most important in specie insurance which whereby the creditor can guarantee his right received from the indebted mortgagor. However, this insurance may be subject to certain obstacles that render it ineffective to guarantee the right of the mortgaged creditor, whether it is the creditor's collusion or his fault, especially when one of the partners formulated the mortgage contract in the common money. It depends in this case on the result of the division or the rest of the partner's endorsement. This mortgage may be restituted to all common money or the partner's share or on a parceled part. All these cases have their own judgments differing from one another in terms of providing adequate insurance for the creditor.

The research deals with important legal problems by answering several questions. Does the mortgage, if restituted to the common money, guarantee the right of the mortgaged creditor in all cases? In other words, does the mortgage continue beyond the division? Does the Iraqi Civil Code guarantee all the possibilities that may result from the distribution of the mortgaged common money including the creditor's state of complicity in the proportion of part of the mortgaged subject?

\section{First: the nature of the mortgage}

In order to show the nature of the mortgage, it is necessary to identify and state the main characteristics of it through the following units:

\subsection{Definition of mortgage}

A term defined by the Journal of Judgments ( the Journal of Ahkam Aladlyiah) in Article 701 as "the sequestration of money until the right is paid. This money is a mortgage. It can be stated from this article that the journal organized one type of mortgage namely the possessory mortgage, because the insurance mortgage does not result sequestration at mortgagee or at justice. 
The Iraqi Civil Code did not define the mortgage in general, but defined the insurance mortgage and possessory mortgage separately, because of the variation of these two systems. The insurance, possessory mortgage and their characteristics will be shown as follows:

The Iraqi legislator defined in Article (1285) the authentic mortgage as "a contract by which a creditor acquires an immovable destined to pay his debt a right in rem by which he obtains preference over ordinary creditors and the creditors who come after him in rank (order) for the repayment of his right out of the price of the immovable no matter into whose hands (possession) the immovable has passed.

It is noted in this legislative definition that the legislator used the term (pay his debts) in the original article, in order to fulfill the right of the creditor, but it would have been more correct to use it (to pay his right) since the right of the creditor to meet (commitment or debt) (1) (3/69) of the Iraqi Civil Code ${ }^{1}$. However, the term "right" was used at the end of the definition, and the laws that used the "right" instead of "debt", such as article 1372 of the Jordanian Civil Code in the definition of the possessory mortgage (the estate possessory mortgage is the retention of money in the hands of the creditor or in the justice for guaranteeing a right that can be paid from all the money or some by precedence over other creditors). Similarly, this is mentioned in the Code of Justice in Article $701,{ }^{2}$ in addition to the use of the word of truth instead of debt in its definition of the right of mortgage ${ }^{3}$.

Through the mentioned details and the legal texts several characteristics of the authentic mortgage can be drawn as follows:

1. The authentic mortgage is a source agreement as there is no authentic mortgage without agreement, but it must be a

\footnotetext{
${ }^{1}$ As provided for (3) The expression (commitment) and the word (debt) are the same as the expression (the personal right).

${ }^{2}$ Dr. Mohammed Labib Shanab, Lessons in Personal and in Rem Insurance, Arab Renaissance House, Cairo, no edition, 1975, p.15.

${ }^{3}$ For further details see Dr. Saadi Isma'il al-Barzanji, Critical Notes in the Civil Law, 1, Ministry of Agriculture Press, Hawleyer-Kurdistan 2007, p. 8 and beyond.
} 
The Fate of the Partner's Mortgage after Division

A Comparative analytical study in the Iraqi Civil Code

Hallo Mohammed Salih Abdulsamad

Safaa Shakoor Abaas

Fryad Shukur Hussein

مجلة وادي النيل للاراسات والبحوث الإنسانية والاجتماعية والتريوية (مجلة علمية محكمة)

formal agreement ${ }^{4}$ registered with the Real Estate Registration Department to hold the authentic contract ${ }^{5}$.

2. The authentic mortgage grants the mortgagor in rem right to the mortgaged property, since the mortgagor has the in rem right and priority over the other ordinary creditors and the following subordinated creditors, and if the mortgagor withdraws from possession of the mortgage, the creditor has the right to follow it at any possession it could be ${ }^{6}$.

3 . authentic mortgage is an in rem real property right that only be to real estate or in rem real property rights?

4. It is an indivisible right where each part of the mortgage is sufficient to pay the whole right of the creditor and the right of the mortgagor is guaranteed to all creditors ${ }^{8}$.

5. authentic mortgage is a right related to the mortgaged object in terms of property and value and not object itself. So, any sum of money of the mortgagor is transferred to the right of mortgagor or paid the right out of the price. This was confirmed by the article (1304) in the Civil Law by saying (the creditors mortgagees will receive their rights before the ordinary creditors out of the price of the mortgaged immovable property or out of the property which substitutes this immovable where each one of them will receive his right

${ }^{4}$ Dr. Mr. Ayed Nayel, Provisions of the Personal and In-kind insurance, no publisher's title and edition number

${ }^{5}$ Article (1/1286) of the Iraqi Civil Code Dr. Mohamed Taha Al-Beshir, AlWajiz in the subsidiary in-kind Rights Print 4, Dar al-Huriya for Printing Baghdad, 1976, p

${ }^{6}$ Article 1286 of the Iraqi Civil Code.

7 Article (1285) of the Iraqi Civil Code, recently some machines may be mortgaged according to certain procedures which are considered in more detail. Dr.. Ghani Hassoun Taha and Muhammad Taha al-Bashaer, The Basic and Follow-up Rights, Publications of the Iraqi Ministry of Higher Education, Baghdad, 1982, no edition, pp. 380 and beyond

${ }^{8}$ Article 1294 Iraqi Civil and Article 315 of the Real Estate Registration Law No. 43 of 1971 
according to his rank (in order of precedence). So the right of mortgage is replaced by any money instead the mortgaged exposed to Actual or judgmental loss ${ }^{9}$.

6. The authentic mortgage is a right of the original right that guarantees the payment of the original right ${ }^{10}$ which is based on its validity, invalidity, existence, and absence. ${ }^{11}$

As to the possessory mortgage, it has been defined by the Iraqi legislator as " a possessory mortgage is a contract by which the mortgager gives property to be held in possession of a mortgagee or of an adl against a debt which the mortgagee may collect ( claim in whole or in part from such property having precedence over the ordinary creditors and regardless of whoever has possession of property. $^{12}$

It is worth mentioning that the possessory mortgage is older than the authentic mortgage. authentic mortgage is known only recently after the existence of the real estate registry and the regulation of real estate. ${ }^{13}$ The Islamic jurisprudence defines this type of mortgage only, and it is necessary to property retention. Article (1/706) Rules of Judgmet (Ahkam Al Adliyah) states that "the pledge shall be valid in respect of both mortgager and mortgagee and shall not be made and shall not be subject to retained."

9 Article 1298 of the Iraqi Civil Code provides that "if the property is mortgaged as a security or a tort, the right of the mortgage shall be transferred to the money replacing it shall be transferred as compensation, the amount of insurance and the acquisition allowance for the public utility. The mortgagor has to be paid his right by rank.(1049) Egyptian Civil and 1339 Jordanian Codes

10 Dr. Abdel-Moneim El-Badrawy, in rem Insurance, Cairo, 1973, No publisher, $\mathrm{p} 12$

${ }^{11}$ 5. d. Ghani Hassoun Taha and Muhammad Taha al-Bashaer, The in-kind Rights, Original and Follow-up, Publications of the Iraqi Ministry of Higher Education, Baghdad, 1982, no edition, pp. 533-352

${ }^{12}$ Article (1321) of the Iraqi Civil Code

137 d. Ghani Hassoun Taha and Muhammad Taha al-Beshir, Previous Citation., P. 354 
The Fate of the Partner's Mortgage after Division

A Comparative analytical study in the Iraqi Civil Code

Hallo Mohammed Salih Abdulsamad

Safaa Shakoor Abaas

Fryad Shukur Hussein

مجلة وادي النيل للار اسات والبحوث الإنسانية والاجتماعية والتربوية (مجلة علمية محكمة)

Through these definitions, and some of the materials, we can draw several characteristics of the possessory mortgage as follows:

1. possessory mortgage is an agreemental resource ${ }^{14}$ as authentic mortgage in which there is no real code in the text of the law or the judgment of the court for the possessory mortgage.

2. It is an in rem right for the mortgager which gives advantages of advancement to other ordinary creditors and the following creditors in rank, and the traceability if the mortgaged is released from the custody ${ }^{15}$ in addition to the sequestration $^{16}$.

3. It is an in rem contract that shall not be pledged until the mortgage is attained by the mortgagor or by justice whether the mortgaged is a movable or immovable property ${ }^{17}$.

4. possessory mortgage includes transferred mortgage and estate property ${ }^{18}$, on the contrary to the authentic mortgage which includes immovable estate mortgage only. ${ }^{19}$

${ }^{14}$ Article 1321 of the Iraqi Civil Code.

15 Tracking is based on the progression feature which means that traceability follows the progress feature. Progress can be found without traceability as in the general privilege rights, but there is no independent tracking without progress.

${ }^{16}$ Dr. Mohamed Kamel Morsi, Explanation of Civil Law, Personal and in-kind Insurance, Knowledge Press, Alexandria 2005, p. 331 d. Al-Sanhuri, Mediation in Civil Law, C10, Personal and in-kind Insurance, 3, Beirut, Lebanon, 2000, p.746

${ }^{17}$ Dr. Muhammad Wahid Al-Din Swar, Explanation of Civil code (subsidiary in-kind Rights) Third Book, First Edition / Fifth Edition, Dar Al-Thaqafa Publishing and Distribution, Amman, Jordan, 2006, p.232

18 Dr. Mohammed Abdel-Zahar Hassin, Personal and in Rem Insurance, (inkind Insurance), c. No Publication, Place and Publishing House, 2002, p. 189

19 Dr. Qusay Salman, The in-kind Rights, 1, Jihan University Press, Arbil, 2012, p 
5. The possessory mortgage is an indivisible right, ie, the whole mortgaged and each part of it guarantee of all debt ${ }^{20}$ unless the agreement otherwise requires ${ }^{21}$.

\section{Second: the effect of the division on mortgage issued by one of the partners}

Common ownership does not necessarily last forever, but may be subject to division after the action of one of the partners and before the execution of the disposition. This individual act of the partner may have all the common money and may be in its common share and may be in a fraction of the common money. For rules disparity of each case from others they will be addressed in separate units as follows:

\section{2-1: The effect of the division on the mortgager of common money}

One of the general principles of composition is that each partner has a full ownership property to which he has the right to dispose within the quota. It is deemed to be opposite if the disposition exceeds the ownership of his partner. Thus, Article (1/1062) of the Civil Code stipulates that " A co-owner of the common ownership is a strange as far as concerns the jointly owned share of the other co-owner and may not dispose of it in such manner which is in any way prejudicial to it without such other co-owner's consent. In other words, a co-owner exceeds his share, which is an act in the possession of the other, and thus he is subject to the owner's permission - the rest of the partners - and the remaining co-owners cannot leave this behavior. This may include either:

The mortgagor may be unaware of this act in the possession of the other, ie he is of good intention and does not know that the creditor is acting his ownership and of the rest of his co-owners,

${ }^{20}$ Article (1/1332) of the Iraqi Civil Code, which is similar to Article 1333 of the Jordanian Civil Code.

${ }^{21}$ Article (1041) of the Egyptian Civil Code. 
The Fate of the Partner's Mortgage after Division

A Comparative analytical study in the Iraqi Civil Code

Hallo Mohammed Salih Abdulsamad

Safaa Shakoor Abaas

Fryad Shukur Hussein

مجلة وادي النيل للاراسات والبحوث الإنسانية والاجتماعية والتربوية (مجلة علمية محكمة)

especially in the possessory mortgage ${ }^{22}$ whether the mortgage is transferred or whether creditor is aware or is supposed to know that he is acting the possession in absence of any intention. According to the general rules, the mortgagor may request a revocation of the contract for the mistake in which he believed to be the owner of the property jointly. Conversely, if the mortgagor knew the status of the creditor, the contract should not be repealed, but the contract is valid and shall be effective for other partners and shall wait for the outcome of the division. If the mortgage is within the share of the mortgagor, the contract then would be valid such as the mortgage is indivisible in rem and the mortgagor purchased the shares of other co-owners.

\section{2_2: The effect of the division on the co-owner mortgage of common shares}

The co-owner acquires his common money totally and then he has the right to act to sell or mortgaging and etc. this act shall be right if he proceeds to sell or give $\mathrm{it}^{23}$, for example, his ownership is transferred from the mortgagor to the buyer ${ }^{24}$. In this case, it is burdened with the same condition. If the common money is distributed during the term of the mortgage and a creditor's portion of the money is deposited and transferred to the same rank to the deposited. The first paragraph of Article 1291 of the Iraqi Civil Code: (1) where a partner of a jointly owned immovable has

\footnotetext{
${ }^{22}$ This possibility cannot be assumed in the authentic and possessory mortgage due to the complex registration and registration procedures. The mortgagee can look up the state of the property in all respects and to the seriousness of the procedures laid down in Articles 305 and beyond of the Iraqi Real Estate Registration Law No. 43 of 1971 Rate.

${ }^{23}$ Article (1/1061) An Iraqi civilian Code, article (1/826) Egyptian civil code and article (1/1030) Jordanian civil code.

${ }^{24}$ It is said that a mortgage is an act of disposing between benefit and harm rather than management, so it requires the necessary eligibility to endorse the act of disposing. Dr. Sanhuri al-Wasit, op. Cit., P. 10, p. 337 and following.
} 
constituted a mortgage on his jointly owned share the mortgage will after the partition has been made be transferred to the parceled share which fell to the lot of this co-owner, ${ }^{25}$ but what is the basis for the transferring of mortgage from the common share to the parceled quota that occurred in the mortgagor's lot?

The jurists argued on the basis of the transfer of mortgage from the common share to the parceled part of the mortgagor's lot. Some considered it a natural influence to divide where the mortgagor is the owner of the stake since the beginning of the contract. ${ }^{26}$ This is what the Iraqi legislator stated in Article 1075, (in a partition parceling has preference over exchange; every partitioner will be deemed as having always been the owner of the parceled share which developed upon him and that he did not at all own anything of the other shares.

Other jurists trended to the view that ${ }^{27 \prime}$ the mortgage transfer from the common share to the parceling part is based on the actual solutions and not on the effect of the division considering that the parceled share of the mortgagor is a natural consequence of the exchange of each part of the mortgagor's share of the common money in exchange for the part that has been concentrated in the mortgagor's care. We support the latter opinion, for it is based on a logical argument above, on the one hand, and on the other hand as the Articles 1298 and 1291 of the Iraqi Civil Code emphasize the principle of solutions. Why the legislator took the in rem solutions in the cases where the mortgagor is not the reason for the expiration of the pledge as in the case in Article (1298) did not take

${ }^{25}$ Article (2/1039) is an Egyptian civil, and Article (1/331) is a Jordanian civil code

${ }^{26}$ Dr.. Ghani Hassoun Taha, Muhammad Taha al-Beshir, op. Cit., P. 391, d. Mohammed Kamel Morsi, A Summary in personal and in rem insurances, Cairo, World Press, 1949, p. 111, d. Abdel-Moneim Farag al-Sadah, The Original in-kind Rights, Beirut, Dar al-Nahdah al-Arabiya for Printing and Publishing, 1982, p.

${ }^{27}$ Dr . Ahmed Abdul-Razzaq al-Sanhuri, al-Wasit, op. Cit., P. Dr.. Hassan Ali Al-Dinon, The in-kind Right, No Place and Year of Publication, p65. Mansour Mansour Mansour, Analysis of the impact of common money distribution 
The Fate of the Partner's Mortgage after Division A Comparative analytical study in the Iraqi Civil Code

Hallo Mohammed Salih Abdulsamad

Safaa Shakoor Abaas

Fryad Shukur Hussein

مجلة وادي النيل للاراسات والبحوث الإنسانية والاجتماعية والتربوية (مجلة علمية محكمة)

in the cases where the mortgagor has caused his property to expire as in the case of a gross fault in mortgaging the share of his partners and may be bad intentions.

Bad intention must be reciprocated. Moreover, one of the most important characteristics of the mortgage is that it is a guarantee with the value of the thing and its value, not the thing itself, that is, the value of the thing is considered in the guarantee of the right of the creditor and which is reassured by the mortgagor on the basis of its value. exchanging a thing or replacing the mortgage shall not affect this warranty

If the mortgagor is pledged his common share of the mortgaged and after the division, another estate mortgage other than he mortgaged.

In this case, the mortgage is invalid and ineffective in Iraqi law because it is not dealt with in contrast to the Egyptian Civil Code, which transfers this mortgage by rank to the property that replaced it. Article (2/1039) stipulates that if a partner shares his common share in the real estate or a parceled part of this property, and then falls into his share when dividing the kinds of property other than those mortgaged, the mortgage is transferred to those kinds which equalize the value of the mortgaged property originally. This amount is quantified by an order written on a petition where a mortgaged creditor makes a new record showing the amount to which the mortgage has moved within 90 days of the time he is notified of the registration of the division. In this regard, it does not affect any if the mortgage is made by all partners and not by the privileged parties).

The rule of Egyptian Code appears to be more correct because it guarantees the right of the mortgagor, who has arranged on the basis of the value of the mortgage his financial affairs, which leads to the stability of the transactions. Moreover, the mortgage as stated above goes with the price and the value of the thing and not the thing itself. Since the value of the mortgage remains still, the mortgage is supposed to be so. Furthermore, in many cases the 
legislator tried to ensure the mortgage perpetuation upon the mortgagor's and mortgagee's will as the article (2/1297), stated 1 that the option to remain the mortgage would be presumed to the mortgagor if the cause of the loss is a force majeure and the choice is then for the mortgagee when it was caused by the mortgagor. ${ }^{28}$ If we measure the case of a non-occurrence of part of the common mortgaged in the creditor's share for non-controllable reasons with a force majeure, then the pledge must remain at the will of the mortgagor. If the cause of loss is the mortgagor himself, then the option for the mortgagee to preserve his right is guaranteed immediately. The legislator may have dealt with the loss of power by force majeure more securely than the occurrence of another impawned mortgage within the mortgagor's share. In case of the loss of mortgage, it is possible to remain the mortgage by the will of the creditor when presenting another warrant.

- In the case of non-mortgaged in the mortgagor's share due to division then the mortgage is abated directly. The mortgagor may comply secretly with the rest of the co-owners in order to obtain the money of the impawned mortgage to flee from the mortgage and the redemption of the mortgaged. Is not this a judgmental loss by the mortgagor? Even in the case where the division by the judiciary of the interest is to be sentenced to loss by force majeure.

\section{3_2: The effect of the division on the individual mortgage on a parceled segment of the common money}

It is known that the partners own the common money and each partner has a share in the account of half, quarter and one third of each atom of common money, without any partner having any part of it, and as we mentioned in the case of pre-division, each partner

${ }^{28}$ Protecting each partner from the actions of others, "Journal of Legal and Economic Sciences, Year 6-13, First Edition, Ain Shams University Press, 1964, p. 188, Dr. Sameer Abdel-Sayed Tannago, Personal and In-kind Insurance, Al-Ma'aref Establishment, 1995, p. Nabeel Ibrahim Saad, Original in-kind Rights, Judgments and Sources, "Al-Ma'aref Establishment, Alexandria, 2001, p.134 
The Fate of the Partner's Mortgage after Division A Comparative analytical study in the Iraqi Civil Code

Hallo Mohammed Salih Abdulsamad

Safaa Shakoor Abaas

Fryad Shukur Hussein

مجلة وادي النيل للاراسات والبحوث الإنسانية والاجتماعية والتربوية (مجلة علمية محكمة)

has the right to act in his share according to the law, provided that it does not harm the rest. While if the common money is divided, each partner has a separate share of this common money and his ownership is concentrated in this part only since he owns the money that is common as if he was not the owner of any of the pence of money occurred in the share of other partners as a result of the retroactive effect of dividing ( $(1$, if we assume that one of the partners may mortgage a parceled part of money for the mortaged creditor before the division. What is the fate of mortgage if the common money is divided before the expiry of mortgage?

After division, there are several possibilities:

1. The occurrence of the parceled portion is within the mortgagor's share, so that the mortgage is valid as the mortgagor is the owner of this part based on the effect of the division and according to article (2/1062) of the Iraqi Civil Code.

2. The second possibility is that the part of the mortgaged does not occur in the mortgagor's share, but that another part or another parceled property is included in his share. In this case, there is no trace of mortgage $\left({ }^{29}\right)$ because it is the dispose of the property of the non-owner who assumes that it was not the owner of the property in Iraqi law, while in Egyptian or Jordanian civil law, we saw a different provision. Article (2/1031) of the Jordanian Civil Code stipulates that: "If the disposition is based on a parceled part of the common money and this part is not included in the owner's share when dividing, then the right of disposition is transferred to the part of the owner of disposition at the time of dividing. If the latter does not know that the former has no property which is

${ }^{29}$ 1. Dr.. Sanhuri, al-Wasit, previous. Citation., P. 8, p. 535

13 
parceled when signing the contract, then he would have the right to annul the act of disposition ${ }^{30}$.

If we consider this text and the text of the Egyptian article (2/826). We can see that this case was treated well in many ways: that the mortgagor got the impawned other's part because he gave up his share in every atom of the common money that occurred in the remaining part of the co-owners in exchange for their waiver of this part of the share in which any part thereof is replaced shall be replaced by their shares in the other parts of their other partners.

On the other hand, as we have stated, the mortgage is based on the value of the thing and its price, not the thing itself. Therefore, we see that it is not necessary for the mortgage to remain the same as the one that was signed, but it can also move to something else instead as stated by the Jordanian and Egyptian Codes. If there is an option to remain the mortgage for this purpose on the one hand, and on the other hand, the survival of the mortgage leads to stability of the transactions, especially if the creditor has secured the mortgage and arranged it on this basis. Mortgage nullification threatens these transactions and miss opportunities from both parties to hold the mortgage indirectly. In addition, we see that the Iraqi legislator allowed the transfer of the right of the mortgagor to the money that replaces the subordinates in Article 1298. (the right of mortgagee is transferred to the property which substitutes it such as compensation on account of expropriation for public utility. (1) it is probable that the mortgage will be transferred to the property to be replaced.

\section{Conclusion}

At the end of research, it has come up with the following results and recommendations as follows:

30 Dr.. Ghani Hassoun Taha, and Muhammad Taha al-Bashir, previous. Citation., P. 394. 3 Article (2/826) of the Egyptian Civil Code has the same meaning. 
The Fate of the Partner's Mortgage after Division

A Comparative analytical study in the Iraqi Civil Code

Hallo Mohammed Salih Abdulsamad

Safaa Shakoor Abaas

Fryad Shukur Hussein

مجلة وادي النيل للاراسات والبحوث الإنسانية والاجتماعية والتربوية (مجلة علمية محكمة)

\section{Results}

1. The Iraqi Civil Code was not precise in its definition of the authentic mortgage when it used the word "to pay his debts" because the term "debt" is synonymous with the obligation in Iraqi civil code, which is viewed by the debtor and which meets the right of the creditor.

2. The Iraqi Civil Code has not adequately protected the mortgaged, in the case of pledging the mortgagor his coowner's share, because he knows or is supposed to know that he is acting in the property of another, so he should treat the creditor who has suffered the wrongdoing.

3. 3 The Iraqi Civil Code did not address the situation of falling into the share of the creditor-partner mortgaging a property other than the one signed by the mortgage, which led to the failure to achieve the pledge, that the mortgage in Iraqi law loses his strength as security in some cases as a result of the division.

4. The Iraqi legislator relied on the in rem solutions in the case of legal loss to the mortgaged when the mortgaged is replaced by another money. furthermore, he did not adopt it in the case of other kinds which are not mentioned in the pledge of creditor's share due to the distribution of the mortgaged common money.

\section{Recommendations}

1. Amending Article 1285 of the Iraqi Civil Code and replacing the term "right" instead of "debt" as debt is a derogation of the right in Iraqi civil Code.

2. Amend the first paragraph Article (1291) as follows (1) If one of the partners mortgaged his common share in a real estate property, the mortgage shall be converted into the parceled share after dividing that has occurred in the share of this partnership. In case the partner got other kinds of unmortgaged before, the mortgage within its 
rank shall be transferred to specified kinds equalizing the value of the property that was originally entrusted to him, and shall be followed in determining the registration procedures for the mortgage.

\section{References}

\section{First: legal books.}

1. Dr. Saadi Isma'il Al-Barzanji, Critical Notes in Civil Law, I, Press of the Ministry of Agriculture, Hawler-Kurdistan, 2007.

2. Dr. Mr. Ayed Nayel, the provisions of the personal and in rem guarantee, without the publisher's title and the number of the edition, 2001

3. Dr. Samir Abdel-Sayed Tandou, Personal and In-Kind Insurance, Knowledge Facility. 1995

4. Dr. Hassan Ali Al-Din, The in-kind Rights, No Place and Year of Printing.

5. Dr. Abdul Razzaq Ahmed Al-Sanhuri, Al-Wasit in Explaining Civil Law, C10, Personal and in-kinds Insurance, I3, Beirut, Lebanon, 2000.

6. Dr. Abdul Razzaq Ahmed Al-Sanhuri, Al-Wasit in explaining the Civil Code, C8, property Rights, I 3, Beirut, Lebanon, 2000

7. Dr. Abdel-Moneim El-Badrawi, The In Rem Insurance, Cairo, 1973, without the publisher.

8. Dr. Abdel Moneim Farag Al-Sadah, The Original in-kinds Rights. Beirut, Dar al-Nahdah al-Arabiya for Printing and Publishing, 1982.

9. Dr. Ghani Hassoun Taha and Muhammad Taha al-Beshir, The in Rem Rights, Original and Follow-up, Publications of 
The Fate of the Partner's Mortgage after Division A Comparative analytical study in the Iraqi Civil Code

Hallo Mohammed Salih Abdulsamad

Safaa Shakoor Abaas

Fryad Shukur Hussein

مجلة وادي النيل للاراسات والبحوث الإنسانية والاجتماعية والتربوية (مجلة علمية محكمة)

the Iraqi Ministry of Higher Education, Baghdad, 1982, no edition.

10. Dr. Mohammed Taha Al-Basair, Al-Wajiz in the Rights of the in-kind rights. No. 4, Dar al-Huriya for Printing Baghdad. 1976

11. Dr. Mohamed Kamel Morsi, Explanation of Civil Law, Personal and in rem Insurance, Knowledge Ltd Press, Alexandria 2005.

12.Dr. Muhammad Wahid Al-Din Sowar, Civil Law Commentary (in-kind rights) Third Book, First Edition / Fifth Edition, Dar Al-Thaqafa Publishing and Distribution, Amman-Jordan, 2006.

13. Dr. Muhammad Labib Shanab, Lessons in Personal and in rem Insurance, Arab Renaissance House - Cairo, no edition, 1975.

14. Dr. Mohamed Abdel-Zahar Hassin, Personal and Personal Insurance, (in rem Insurance), c. No Publication, Place and Publishing House, 2002.

15. Dr. Nabeel Ibrahim Saad, Original in rem Rights, Judgments and Sources, "Al-Ma'aref Establishment, Alexandria, 2001.

\section{Second: Research and Articles:}

1. Dr. Mansoor Mustafa Mansour, Analysis of the effect of common money distribution and protection of each other's share of the actions of others, Journal of Legal and Economic Sciences, 6th year -1313, Ain Shams University Press, 1964. 


\section{Third: Laws:}

1. The Iraqi Civil Code (40) for the year 1951 amended.

2. The Iraqi Real Estate Registration Law No. (43) of 1971 amending.

3. The Iraqi Acquisition Code No. (12) of 1981.

4. The Egyptian Civil Code No. (131) for the year 1948 amended.

5. Jordanian Civil Code No. (43) of 1976. 